\title{
Sinuolinea tetraodoni n. sp., a myxosporean parasite of freshwater pufferfish Tetraodon palembangensis from Southeast Asia - light and electron microscope observations
}

\author{
M. El-Matbouli, R. W. Hoffmann \\ Institute of Zoology, Fish Biology and Fish Diseases, Kaulbachstr. 37, D-80539 Munich, Germany
}

\begin{abstract}
Sinuolinea tetraodoni n. sp. from the lumen of the kidney tubules and renal corpuscles of pufferfish Tetraodon palembangensis imported from Southeast Asia (Thailand, Sumatra) is described and illustrated. It is distinguished from all previously described members of the genus by the shape and the small size of the mature spore (length $9.56 \pm 0.51 \mu \mathrm{m}_{\text {i width }} 10.11 \pm 0.52 \mu \mathrm{m}$ ), the presence of a desmosome-like junction connecting the 2 spores in the pseudoplasmodium, and its geographical distribution. Prevalence of infection was $100 \%$ in examined fish. Two triangular spores perpendicular in plane to the suture, developed within the surrounding pseudoplasmodium. Thin valves surrounded the binucleate sporoplasm cell and 2 spherical polar capsules $(3.19 \times 3.21 \mu \mathrm{m})$. Data concerning ultrastructure and sporogenesis are also presented.
\end{abstract}

KEY WORDS: Sinoulinea spp. Myxosporea - Tetraodon palembangensis - Southeast Asia

\section{INTRODUCTION}

Sinuolinea spp. (family: Sinuolineidae) have been described from different species of fish. To our knowledge 10 species of this myxosporean have been described, all of them from marine fish (Table 1). J. Lom (pers. comm.) noted 3 further species ( $S$. contrariocapsularis Evdokimova, 1972, S. sakinachunumae Ibragimov, 1988, and S. markewitchi Iskov, 1989), which were found in Syngnathus nigrolineatus caspius from the Caspian Sea. Unfortunately, no further details about these species have been available. Davis (1917) was the first to describe and name the genus Sinuolinea in fish from the Beaufort region of the USA. This author characterised the spores of this genus to be spherical or subspherical with 2 nearly spherical polar capsules. The sutural line forms a prominent sinuous ridge around the spore. In the present report, we describe Sinuolinea tetraodoni n. sp. from the kidney of pufferfish Tetraodon palembangensis.

\section{MATERIAL AND METHODS}

While checking the health condition of Asian pufferfish Tetraodon palembangensis imported from Southeast Asia (Thailand, Sumatra) by ornamental fish markets, we found a myxosporean infecting the kidney. Eight fish $(2.4$ to $3.0 \mathrm{~g}, 4.0$ to $5.0 \mathrm{~cm})$ were examined in March-July 1992. Fish were anaesthetised by chlorbutanol (1.1.1-trichlor-2-methylpropanol), $0.1 \mathrm{~g}$ $\mathrm{I}^{-1}$ water, necropsied and all parenchymatous organs studied for both fresh and histological examination. Parts of each organ were sampled and examined in fresh mounts by light microscopy. Morphology of spores and of developmental stages was observed in fresh mounts, dimensions were determined using a Leitz Dialux 20 light microscope equipped with an ocular micrometer and assisted by a computer (model PET $300 \mathrm{I}$; Leitz). Blood smears and kidney impressions were air-dried, fixed in methanol and stained with Giemsa's solution. For histological examination speci- 


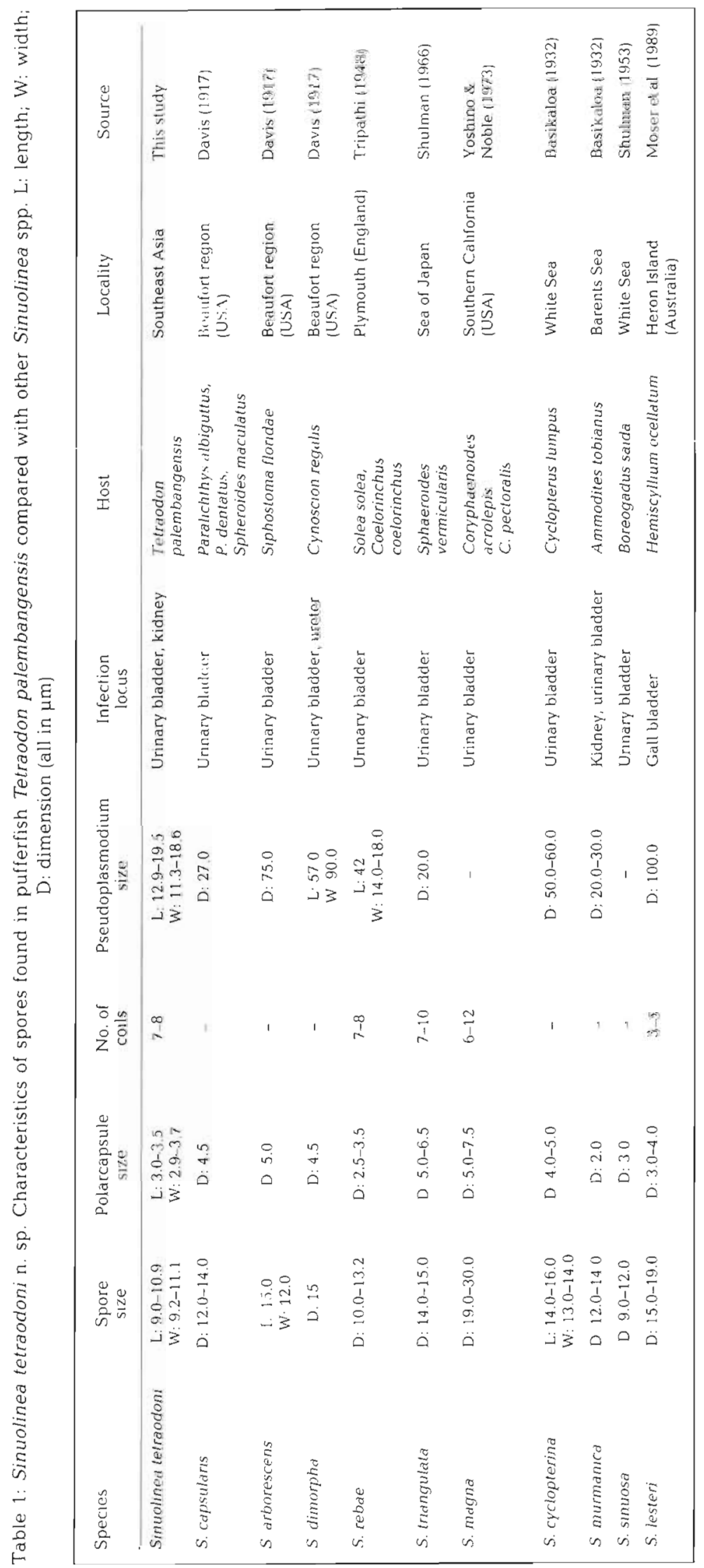

mens were fixed in $5 \%$ buffered formaldehyde and embedded in Historesin ${ }^{3}$. Sections were stained with $\mathrm{H} \& \mathrm{E}$, Giemsa's solution and using the periodic acid-Schiff (PAS) reaction.

Kidney tissues were also fixed in $6.25 \%$ Sörensen phosphate buffered glutaraldehyde (PH 7.4) for $3 \mathrm{~h}$ and postfixed with $1 \% \mathrm{OsO}_{4}$ in the same buffer for $2 \mathrm{~h}$. After dehydration, they were embedded in Epon-812. Semithin sections were stained with toluidine blue and safranin, ultrathin sections were contrasted with uranyl acetate and lead citrate, and then examined by electron microscope (Zeiss EM 109).

\section{DESCRIPTION}

\section{Sinuolinea tetraodoni n. sp. (Fig. 1)}

Host: Pufferfish Tetraodon palembangensis

Locality: Southeast Asia.

Site of infection: Lumen of the kidney tubules, distal and proximal tubules, collecting ducts, renal corpuscles.

Prevalence: 8 of 8 host specimens examined.

Sporogonic stages: These were composed of 12 cells within a pseudoplasmodium in the lumen of the kidney tubules. Two spores developed within each pseudoplasmodium.

Spore characteristics: In the sutural plane spores appeared ellipsoid in shape but in plane perpendicular to the suture they appeared triangular. The suture line was quite sinuate. There were 2 spherical polar capsules near the narrow end of the spore, opening near the suture but in oppo-

Figs. 1 to 4 . Sinuolinea tetraodoni infecting Tetraodon palembangensis. Fig. 1 Line drawings of various sporogonic stages. (A) Early pseudoplasmodium; (B) disporic pseudoplasmodium (C) 2 mature spores connected via desmosomelike junction. Scale bar $=4 \mu \mathrm{m}$. Fig. 2. S. tetrao doni in the lumen of a kidney tubule. Note disporic pseudoplasmodia with mature spores (arrows). Fresh preparation, phase contrast. $\times 1000$. Fig. 3. Mature spores in the lumen of renal tubules. Giemsa, $\times 300$. Fig. 4. Infected distal tubule showing mature spores (arrows). Giemsa, $\times 740$ 

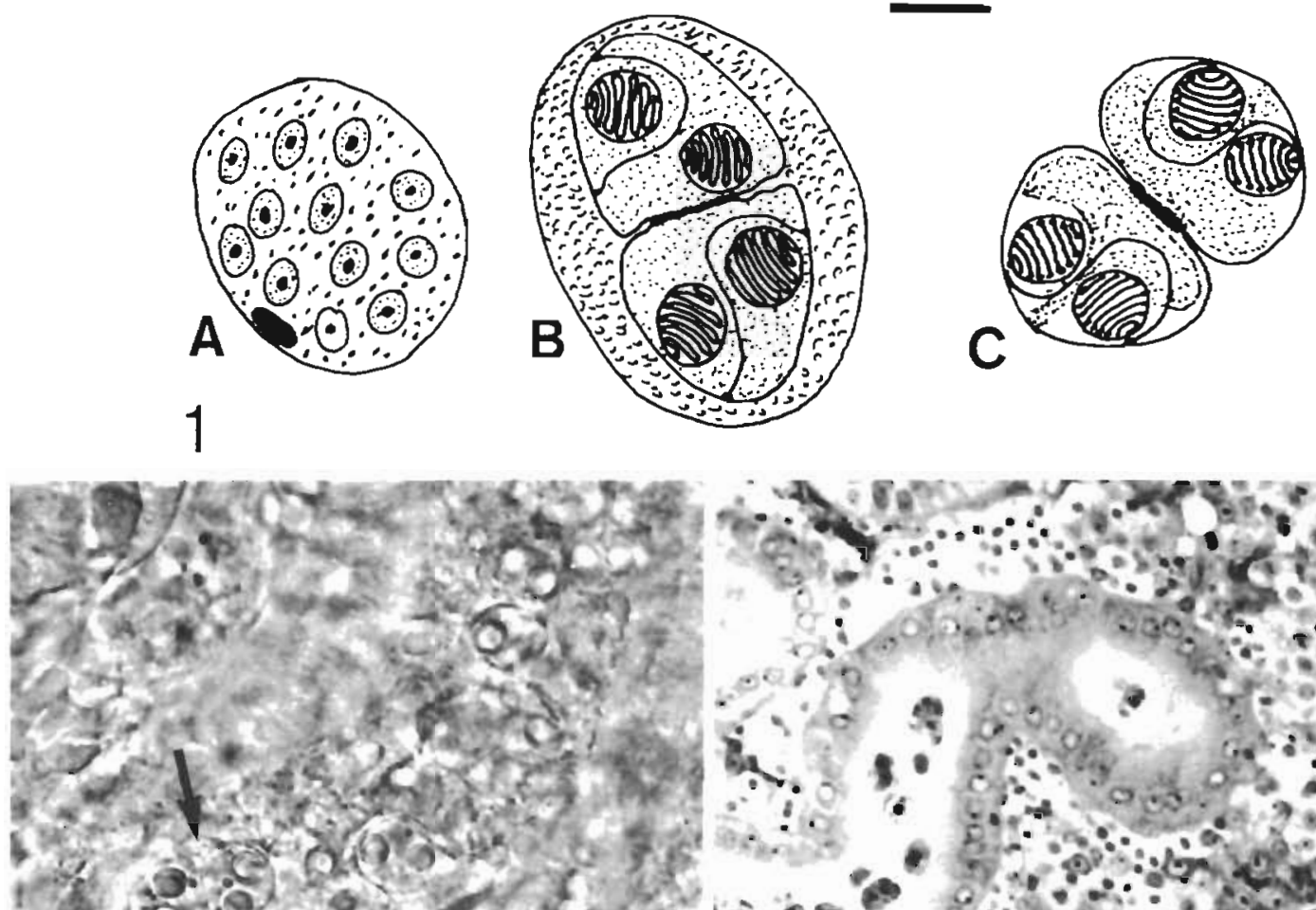

$$
\text { ind }
$$$$
\text { a. } ?^{\circ}-5 \%
$$$$
\text { 1. }
$$

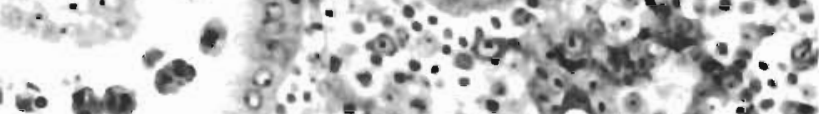

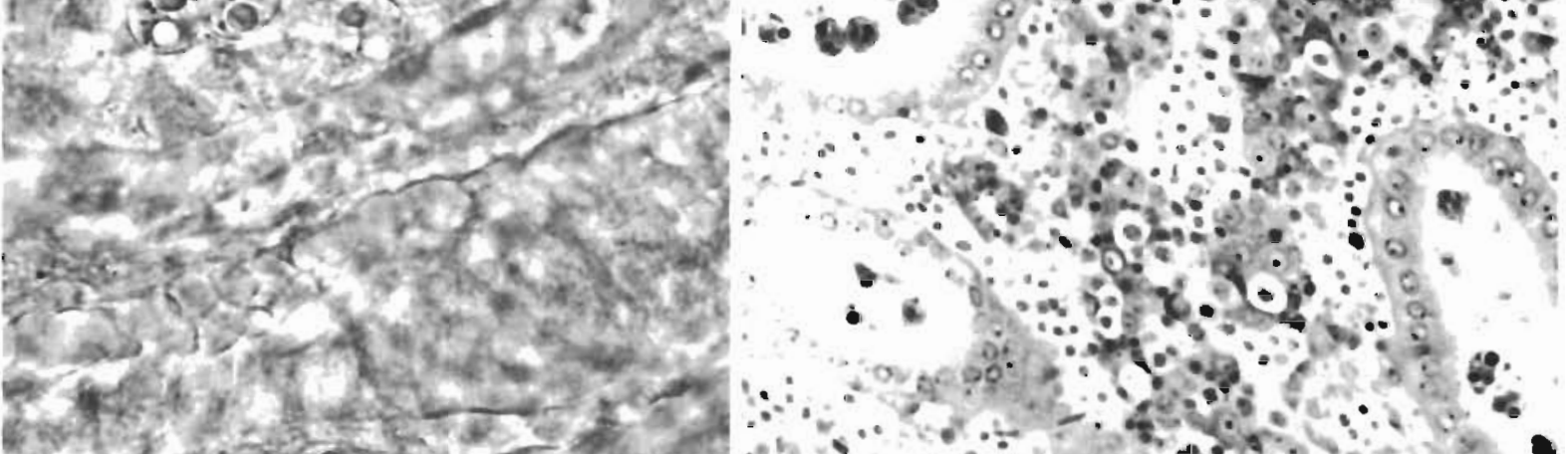

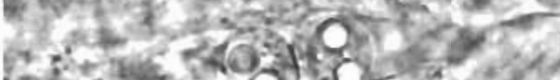

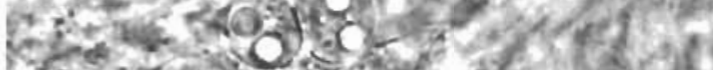

201,200

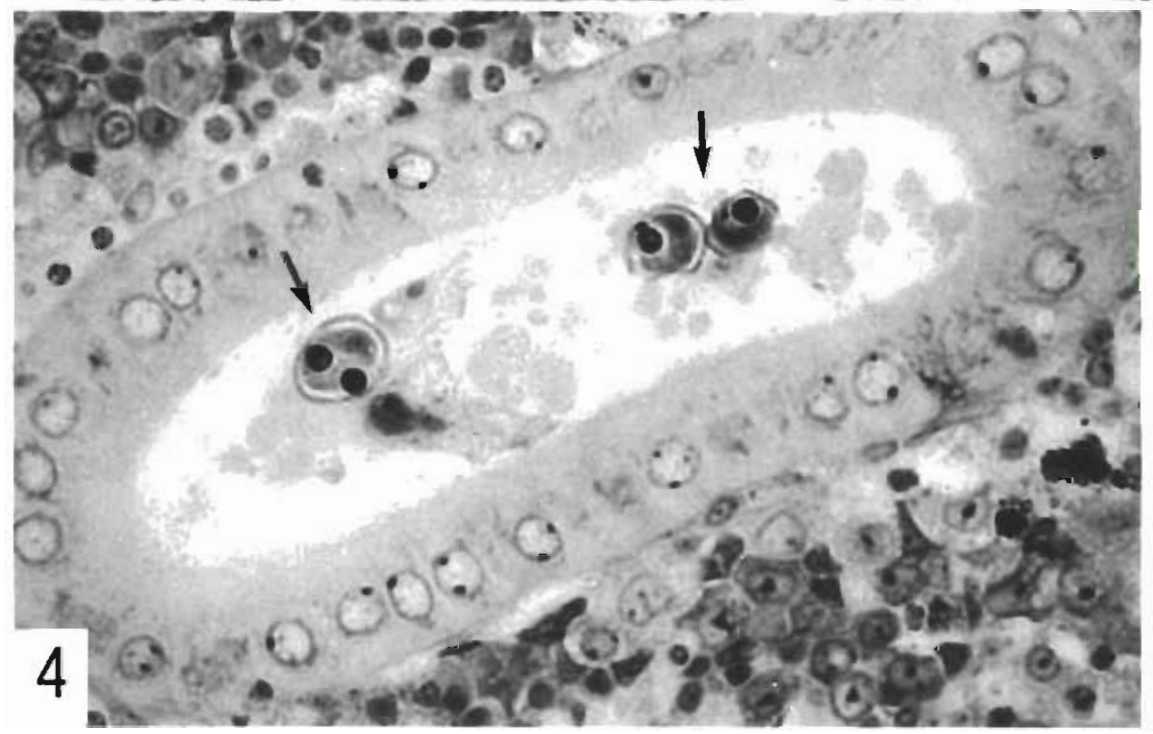


site directions. The sporoplasm had 2 nuclei. Mean length of the spore $(n=50)$ was $9.56 \pm 0.51 \mu \mathrm{m}$, mean width $10.11 \pm 0.52 \mu \mathrm{m}$. Mean length of polar capsules was $3.19 \pm 0.15 \mu \mathrm{m}$, mean width $3.21 \pm 0.22 \mu \mathrm{m}$

\section{RESULTS}

\section{Light microscope observations}

In all 8 examined pufferfish, developmental stages and mature spores of Sinuolinea tetraodoni $\mathrm{n}$. sp. (Figs, 2, $3 \& 4$ ) were found in fresh preparations and tissue sections of the kidney. In fresh imprints from the kidney, every 2 mature spores were usually connected on their flattened side ( $\Gamma \dot{i}$. 5A, B). Pseudoplasmudia found in fresh preparations of the kidney were round to elongate, contained 2 spores and many refractile granules in the cytoplasma of the pseudoplasmodia cells. Examination of histological sections revealed early stages and mature spores of $S$. tetraodoni primarily in the distal and proximal tubules of the kidney (Figs. 3 \& 4). In some cases, spores and developmental stages were also detected in Bowman's space and glomerular capillaries of the renal corpuscles (Fig. 6). Developmental stages appeared in the same location as spores, but rarely also in the tubular epithelia. In PAS-stained sections, spores exhibited PAS-positive bodies in the sporoplasm and in the shell valves. The cell cytoplasm of the developmental stages was also PAS-positive. Spores were not found in other organs examined. In blood smears no myxosporean developmental stages were observed.

\section{Transmission electron microscope observations}

The pseudoplasmodia in the lumen of the kidney tubules were in close contact with the microvilli of epithelial cells (Fig. 7). At all junctions of tubular epithelial cells, the pseudoplasmodia sent out projections between the microvilli. These projections were about the same length as the microvilli (Figs. $7 \& 8$; see also Fig. 10). At the point of contact with the electron-dense junctions (desmosomes), the tip of the pseudoplasmodia projection also become dense (Fig. 8). The tips of the microvilli however did not form any cell junction with the plasmalemma of the pseudoplasmodia.

The earliest developmental stages observed were 1 cell stages found in the lumen of the kidney tubules (Fig. 9). The first division of this stage resulted in $1 \mathrm{sec}$ ondary cell. enclosed in a primary cell (Fig. 10). The cytoplasm of both these cells contained mitochondria and free ribosomes. These early stages most probably divide to increase the parasite number resulting in primary cells which contained 4 or more secondary cells (Fig. 11). These have to be regarded as initial sporogonic stages. The sporoblast cells started their differentation while in close contact with each other. Each pseudoplasmodium produced 2 spores, usually connected by desmosome-like junctions (Fig. 12). The morphogenesis of the polar capsule followed the same pattern as in species of the genus Sphaerospora. The primordium had a long external tube so that more than 4 transverse sections of the tube could be made out. As assessed from the sections the tube can make 7 or 8 windings inside the polar capsule (Fig. 13). At the stage when the globular capsular primordium had been formed, the valvogenic cells already enclosed the capsulogenic and sporoplasmic cells and adhered toyeiner by desmosome-iike junctions (Figs. i3 \& i4). Ar the stage of a nearly mature spore, large electrondense inclusions appeared in the cytoplasm of the primary cells, thus showing a degeneration process. In the resulting binucleate sporoplasm (Fig. 14), electrondense inclusions (sporoplasmosomes) - characteristics of sporoplasms in most myxosporeans - were lacking. In the tubular lumen of kidneys of infected fish all stages of sporogony occurred simultaneously.

\section{DISCUSSION}

Sinuolinea tetraodoni n. sp. detected in the kidneys of pufferfish in this study are the first to be reported from freshwater fish. All Sinuolinea species listed in Table 1 have different hosts and geographical distribution to those of S. tetraodoni. The shape of S. tetraodoni quite resembles that of S. triangulata (Shulman 1984) in the urinary bladder of Sphaeroides vermicularis from the former USSR. However, the dimensions of $S$. triangulata spores and their polar capsules as described by Shulman (1984) are evidently greater (Table 1).

Among the many papers on myxosporean fine structure, there are none on Sinuolinea. The present findings show that the structure and morphogenesis of the spores of this Sinuolinea species match the characteristic myxosporean pattern. Mature spores of S. tetraodoni have a binucleated sporoplasm. This feature has been reported in only 2 light microscopical (LM) descriptions of Sinuolinea: S. magna (Yoshino \& Noble 1973) and S. rebae (Tripathi 1948).

Disporous development and the presence of desmosome-like junctions between the shells of both spores in the pseudoplasmodium even after maturation observed using both LM and transmission electron microscopy (TEM) seem to be common characteristics of S. tetraodoni.

Capsulogenesis is supposed to proceed along the 

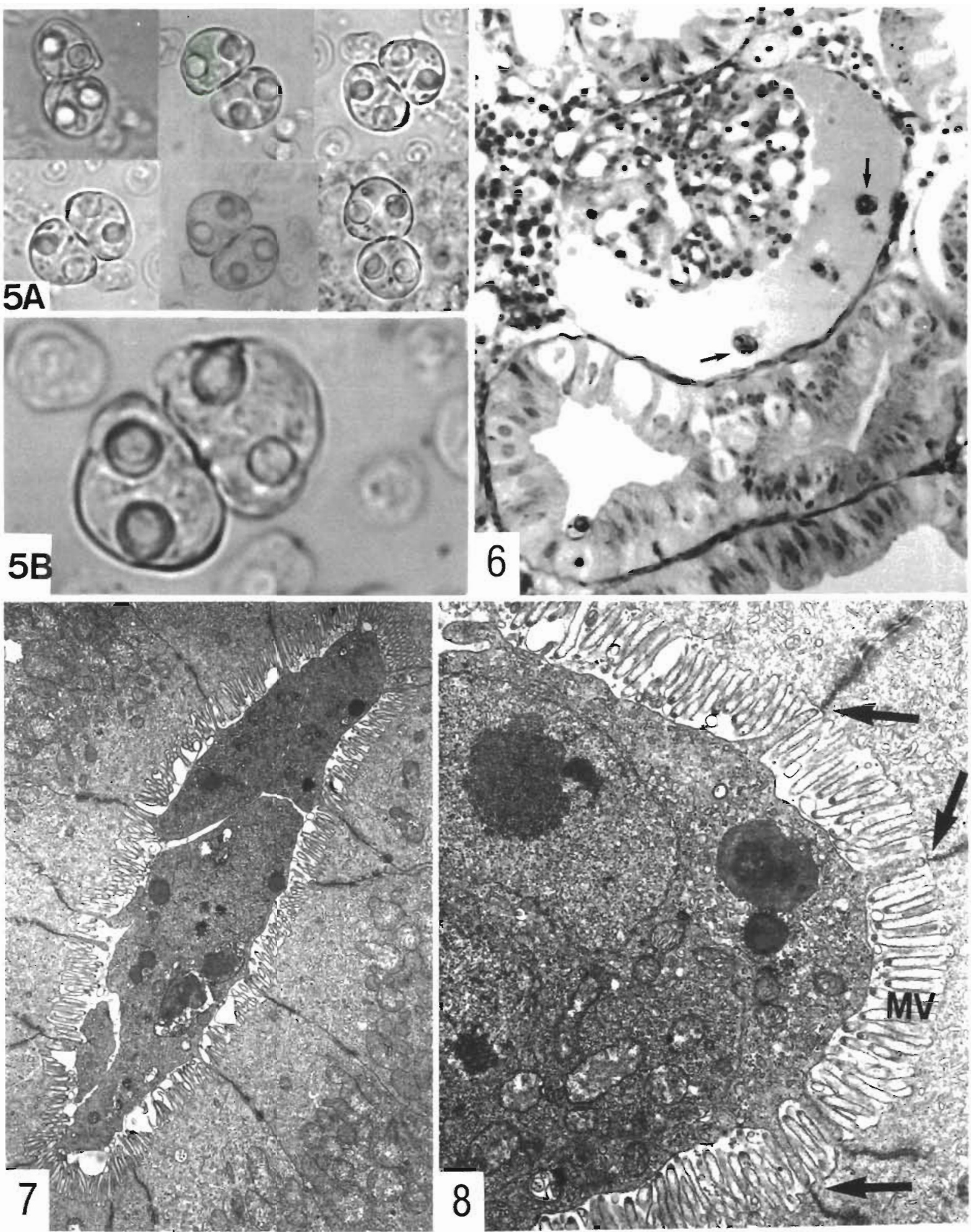

Figs. 5 to 8 . Sinuolinea tetraodoni infecting Tetraodon palembangensıs Fig. 5. Mature spores from fresh preparation. Note the desmosome-like junction between the mature spores $(A) \times 1000$ : (B) $\times 2300$. Fig. 6 . Mature spores (arrows) in the dilated Bowman's space of the renal corpuscles Giemsa, $\times 370$ Fig. 7 . Early developmental stages in close contact with the microvillar zone of epithelial cells of the renal tubule $\times 6300$ Fig. 8 . Pseudoplasmodium in the lumen of the renal tubule Arrows indicate cytoplasma projections extending between ricrovilli (MV) at all junctions of tubular epthelial cells $\times 14500$ 


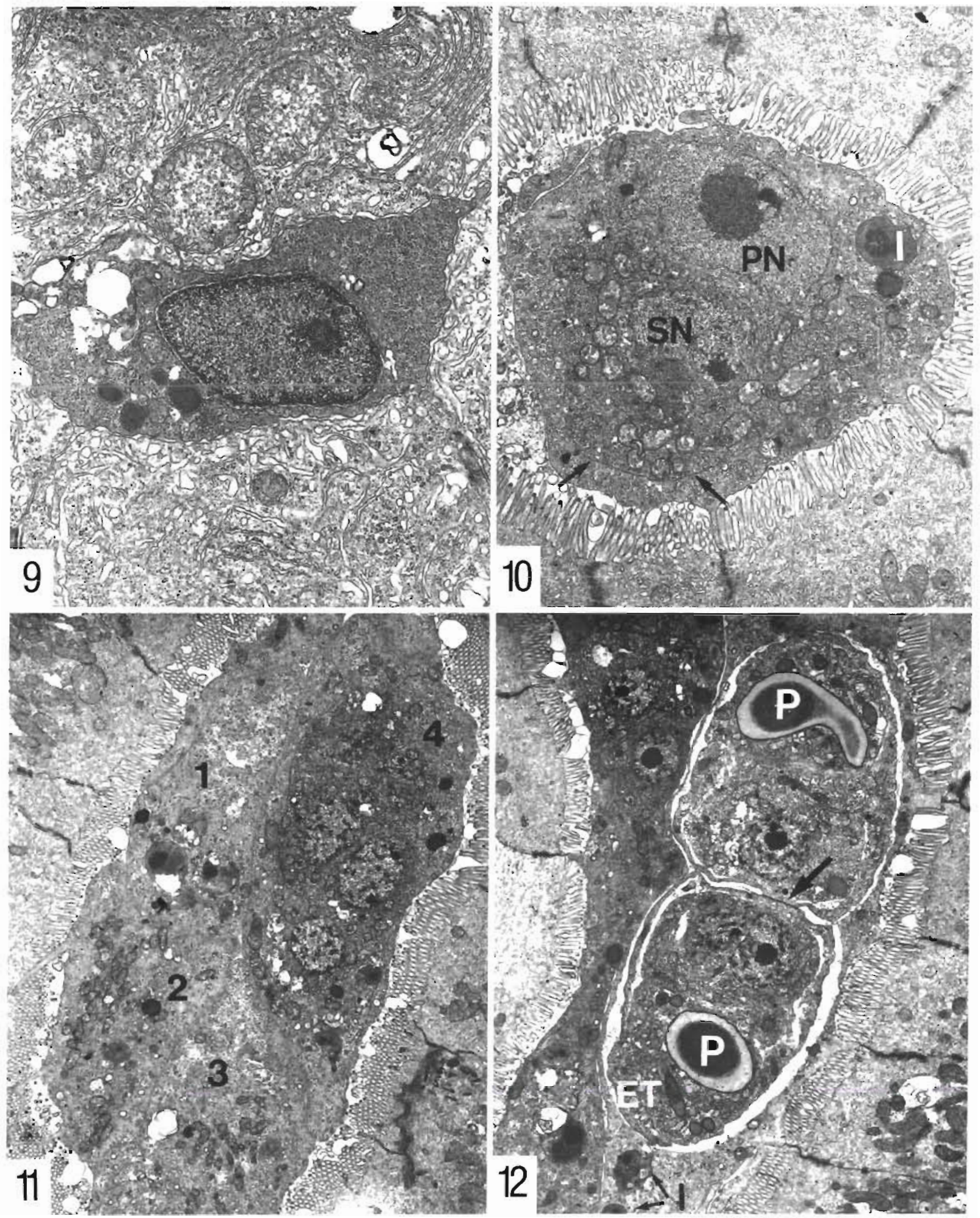

Figs 9 to 12 Sinuolinea tetraodonı infecting Tellaudon palembangensis. Fia. 9 . One-cell developmental stagr of $S$ tetraodonı in the lumen of the renal tubule $\times 14500 \mathrm{Fig} .10$ Pseudoplasmodium with 1 sporogonic cell in the lumen of the renal tubule Arrow cell membrane of the sporogonic cell. PN: pseudoplasmodium nuclei, SN sporogonic nuclei. I: electron-dense inclusions in the cytoplasma of the primary cell $\times 8800$ Fig. 11 . Four pseudoplasmodia $(1$ to 4 ) of $S$ tetraodoni attached to the microvilli of epithelial cells of the renal tubule No 4 is darker in appearance with more ribosomes and harbors 3 visible sporogonic cells $\times 8800 \mathrm{Fig} 12$ Young disporoblast inside a pseudoplasmodium Only 2 capsulogonic cells can be seen p primordıum, ET transverse sections of the external tube, I. opaque unclusions in the cytoplasma of the pseudoplasmodium cell. Note the desmosomeLike junction between the 2 sporoblasts (arrow) $\times 6300$ 

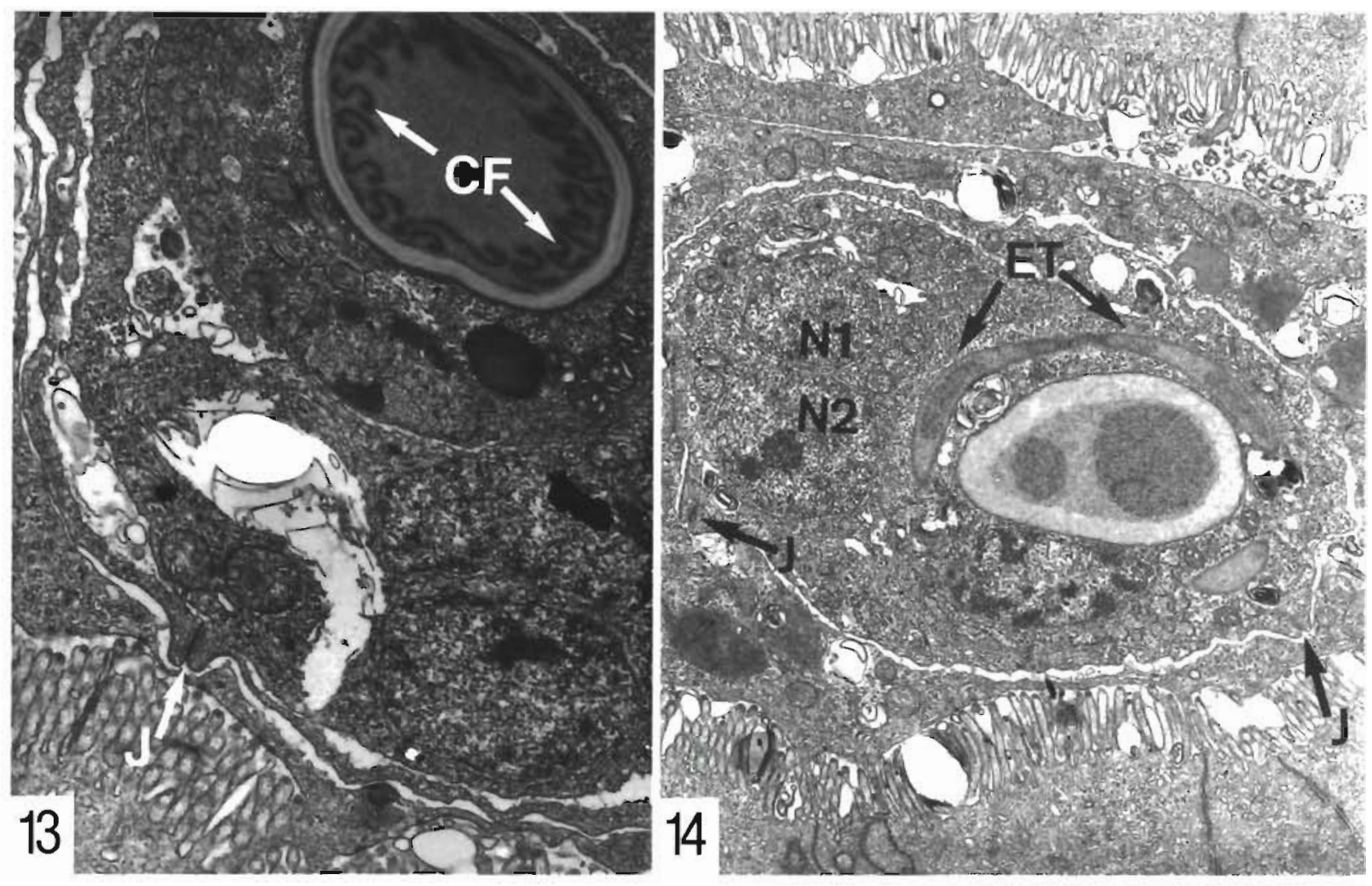

Figs. 13 \& 14. Sinuolinea tetraodoni infecting Tetraodon palembangensis. Fig. 13. Section through a maturing spore showing coils of primordial polar filament (CF) within the primordium. $J$ : junction of the shell valves. $\times 14500$. Fig. 14 . Young sporoblast showing binucleate sporoplasm cell $(\mathrm{N} 1, \mathrm{~N} 2)$. ET. longitudinal section of the external tube; $\mathrm{J}$; junctions of the shell valves. $\times 8800$

pattern observed in most myxosporeans and described by Lom \& Puytorac (1965). Concerning the origin of the polar capsule, present TEM observations of capsulogenic cells in early sporoblasts of $S$. tetraodoni did not reveal the presence of numerous Golgi complexes, but large amounts of rough and smooth endoplasmatic reticulum were observed. This is in accordance with similar observations in Sphaerospora carassii (Desser et al. 1983), Sphaerospora galinae (Lom et al. 1985) and Myxobolus sp. (Desser \& Paterson 1978). In other myxosporeans, the Golgi apparatus seems also to be involved in the development of polar capsules (Lom 1969, Desser et al. 1983, El-Matbouli et al. 1990).

There were no apparent effects on the tubules during the sporogonic stages of development, a finding consistent with other renal myxosporeans (Dyková \& Lom 1982, Molnár \& Kovacs-Gayer 1986, El-Matbouli \& Hoffmann 1992). However, infected renal corpuscles of pufferfish harboring mature and developmental stages of Sinuolinea tetraodoni showed some dilatation of glomerular capillaries and Bowman's space. During our observations no stages could be detected in the blood of infected pufferfish, but the low number of fish examined did not allow us to establish whether blood stages occur or not.
Acknowledgements. We thank Mrs C. Vogt and Ms E. Wanschura for excellent technical assistance.

\section{LITERATURE CITED}

Basikalova, A. (1932). Data on the parasitology on Murmansk fish. Sb. Nauchno-Promysl. Rabot na Murmane, Snabtekhuzdat, p. 136-153 (in Russian)

Davis, H. S. (1917). Myxosporidia of the Beaufort region. A systematic and biologic study. Bull. Bur. Fish., Wash. 35: 203-243

Desser, S. S., Molnár, K., Horwath, I. (1983). An ultrastructural study of the myxosporeans. Sphaerospora angulata and Sphaerospora carassii, in the common. carp, Cyprinus carpio. J. Protozool. 30: 415-422

Desser, S. S., Paterson, B. (1978). Ultrastructural and cytochemical observations on sporogenesis of Myxobolus sp. (Myxosporidia: Myxobolidae) from the common shiner, Notropis cornutus. J. Protozool. 25: 314-326

Dyková, I., Lom, J. (1982). Sphaerospora renicola n. sp.; a myxosporean from carp kidney, and its pathogenicity. Z. Parasitenkd. 68: 259-268

El-Matbouli, M., Fischer-Scherl, T., Hoffmann, R. W. (1990) Light and electron microscopic studies on Myxobolus cotti El-Matbouli and Hoffmann, 1987 infecting the central nervous system of the bullhead (Cottus gobio). Parasitol. Res. 76: $219-227$

El-Matbouli, M., Hoffmann, R. W. (1992). Sphaerospora scardinii n. sp. (Myxosporea: Sphaerosporidae) observed in 
the kidney of rudd (Scardinus erythrophthalmus). Dis. aquat. Org. 14:23-29

Lom, J. (1969). Notes on the ultrastructure and sporoblast development in the fish parasitizing myxosporidian of the genus Sphaeromyxa. Z. Zellforsch. 97: 416-437

Lom, J., Pavlaskova, M., Dyková, I. (1985). Notes on kidneyinfecting species of the genus Sphaerospora Thelohan (Myxosporea), including a new species $S$. gobionis sp. nov., and on myxosporean life cycle stages in the blood of some freshwater fish. J. Fish Dis. 8: 221-232

Lom, J., Puytorac, P. (1965). Studies on the myxosporidian ultrastructure and polar capsule development. Parasitologica 1: 53-65

Molnár, K., Kovacs-Gayer, E. (1986). Experimental induction of Sphaerospora renicola (Myxosporea) infection in common carp (Cyprinus carpio) by transmission of SB-protozoans. J. appl. Ichthyol. 2: 86-94

Responsible Subject Editor: W. Körting. Hannover. Germany
Moser, M., Kent, M. L., Dennis, D. (1989). Gall bladder Myxosporea in coral reef fishes from Heron Island, Australia. Aust. J, Zool. 37: 1-13

Shulman, S. S. (1953). Parasites of fish from the white sea. Izd. Akad. Nauk SSSR, M.-L. (in Russian)

Shulman, S. S. (1966). Myxosporidia of the fauna of the USSR. Nauka, Moscow (in Russian)

Shulman, S. S. (1984). Key to determination of parasites to freshwater fish of the fauna of the USSR, Vol. 1, Parasitic protozoa. Nauka Publ., Leningrad (in Russian)

Tripathi, Y. R. (1948). Some new Myxosporidia from Plymouth with a proposed new classification of the order. Parasitology 39: 100-11.8

Yoshino, T. P., Noble, E. R. (1973). Myxosporida of macrourid fishes from Southern California and Mexico. J. Parasitol. 59: $844-850$

Manuscript first received: Octobor 6, 1903

Revised version accepted: December 28, 1993 